\title{
Editorial: Sexual Spaces
}

\author{
Alison Pullen \& Torkild Thanem
}

The final version of the editorial is published in Gender, Work \& Organization (2010), Special Issue on Sexual Spaces, vol. 17, no. 1, pp. 1-6.

Over the past couple of decades there has been an expanding body of research on sexuality in the workplace, in management and in organizational life (e.g. Burrell, 1984, 1987; Hearn et al., 1989; Filby, 1992; Adkins, 1995; Hearn and Parkin, 1995; 2001; Baugh, 1997; Collinson and Collinson, 1996; Kerfoot and Knights, 1998; Capper, 1999; Brewis and Linstead, 2000; Brewis, 2005; Linstead and Pullen, 2006). Some of this work investigates how organizations and management often seek to exclude sex and sexuality from the ambit of their concerns, so as to desexualize work, management and organizational life (e.g. Burrell, 1984, 1987). Some of it also highlights the ways in which male and masculine sexuality suppresses and excludes female and feminine sexuality in the managerial production of work and organization so as to discriminate against women in the workplace (Hearn and Parkin, 1995, 2001; Collinson and Collinson, 1996).

Concurrent with these developments, social scientists and scholars of work, management and organization have given increasing attention to issues of space and time (e.g. Hatch, 1987; Berg and Kreiner, 1990; Elias, 1992; Burrell and Dale, 2003; Fleming and Spicer, 2004; Dale, 2005; Adam, 2006; Carr and Hancock, 2006). For some, the role of globalization and informatization in reducing the impact of geographical distance and the local peculiarities of place (Giddens 1984, 1990) has produced what Armitage (2001) (following Virilio's "dromology") has called "dromocracy" - and what may be called "rule by speed". But even in 
this virtually enabled world, studies of complexity have alerted us to the potential impact of local variations and their intensities, which have produced a renewed attention to the importance of the local. Space, as Bauman (1998), Castells (2000) and Soja (1994) have pointed out, has a different meaning depending on how we experience the relative advantage and disadvantage associated with our spatialities as members of society. Indeed, there seem to be few symbolic limits on the ways in which people can locally reinscribe and reterritorialize their spaces, whether deciding how to arrange their office furniture, what to do on their holidays, or "dogging" in the park.

While each has been considered separately, work and organization studies has thus far not attended to the various relations between sexuality and space. Also unattended to is the burgeoning research in history and geography, and more recently in sociology and cultural studies, which explores the connections between sexuality and space (e.g. Valentine, 1993; Bell and Valentine, 1995; Grosz and Probyn, 1995; Hubbard, 1999; Hubbard and Saunders, 2003; Binnie and Skeggs, 2004; Bell and Jayne, 2004; Skeggs et al., 2005; Bell, 2006). Examples of this have been research investigating street prostitution and red light districts (e.g. Hubbard, 1999; Hubbard and Sanders, 2003); the appropriation of certain places and areas by sexual minorities (e.g. Skeggs et al., 2005; Bell, 2006); and how "dissidents" transgress public and civic spaces (Hubbard, 2001).

The idea for this special issue developed out of a belief that the intersection of research interests in sexuality with those of spatiality was something that needed to be developed further, both in general, and in relation to issues of work, management and organization. Specifically, we see this special issue as progressing towards opening up some of these debates in Gender, Work and Organization. For this issue we therefore invited theoretical 
and empirical contributions which explored the relations between sex, sexuality and space such as: the ways in which all kinds of public, private, virtual and inner spaces are inhabited by sexual relationships, performances and identity work; the ways in which the sexualizing of particular spaces is organized; and the ways in which the sexualizing of space affects organization. In our call for papers we suggested that these issues could be studied through a number of different spaces, including, but not restricted to spaces of work and consumption: factories and office space, public space and shopping malls, red-light districts, dance clubs and discos, hotels and holiday resorts, hospitals and health-related issues, virtual communities and hi-tech environments, and sexual spaces in the media and film. We also suggested that these issues could be addressed by investigating cross-cultural dimensions of sexuality, spacerelated language and discourse analysis, and genres of sexual space (from pastoral and romantic to techno and post-apocalyptic).

In the issue that follows, we offer five papers which attend to some of these issues albeit in diverse ways. Chris Steyaert opens the issue with 'Queering Space: Heterotopic Life in Derek Jarman's Garden'. At the heart of this paper it is suggested that new forms of sexual identity contests dominant forms of sexuality which become practiced in "other" spaces or "heterotopias". In building this argument, Steyaert utilizes the artist Derek Jarman's garden and gardening practices as heterotopic spaces and practices - gardens being a neglected organized space to be studied. To theoretically establish the relationship between sexual difference and (other) space, the notion of heterotopia is connected to the concept of Foucault's care of the self that is understood as an existential, aesthetical and political activity of (creating) difference. The care of the self is interpreted as a queer practice, which turns a spatial politics of (sexual) difference into one of queering spaces. In concluding, Steyaert argues that organizations need to shift their attention from utopian to heterotopian analysis 
and tentatively explores the consequences of considering organization analysis as a heterotopology. This paper makes an important contribution to the study of organized space and sexuality by exploring how resistance manifests in the spatiality of difference - spaces that disrupt the normalizing discourses of our everyday lives in work and organizations.

The second paper in the issue 'Space, Place and Sexual Sociality' by Adam Green, Mike Follert, Kathy Osterlund and Jamie Paquin locates itself within the "spatial turn" in sociology by highlighting the socializing, cultivating, and pedagogical properties of space in relation to sexual sociality and sexual practice. To do this the authors explore both space and place in relation to research on sexuality and space in historical and sociological writings on public restrooms, bathhouses and SM dungeons as organized sexual spaces. In particular the paper demonstrates how these places and spaces are organized and become organized around sexual activity. This "atmospheric analysis" combines place and space in developing an awareness of how sexual spaces become organized.

Having offered two theoretical papers, the issue then presents three papers reporting empirical research. In the third paper of the issue, Elina Penttinen presents research on the embodied space of a sex bar in Finland. In exploring the intersectionality of sexuality with gender and ethnicity, the paper investigates the ways in which gendered and ethnicized subjectivity and agency emerge for erotic dancers. Using narrative method, the constraints and possibilities of these embodied positions and their organization within a sex bar are illustrated to reveal the situatedness and temporality of subjectivities. Irigaray's formulation of a heterosexual matrix in which women embody a specular function which enables the formation of the masculine subject is used to analyze the subjectivities of erotic dancers. 
In the next paper, Lorraine Nencel presents a study of secretaries in the public sector in Lima, Peru. In particular, Nencel explores the construction of hegemonic sexuality in daily practice, arguing that the miniskirt is imbued with sexual meanings that reflect this hegemonic construction of sexuality. The paper unfolds by first analyzing attempts to ban wearing the miniskirt in the workplace in the public sector; and second exploring female secretaries' experiences, appearances and identities and their associations with the miniskirt. Nencel's analysis highlights how secretaries' rejection of the miniskirt focuses on issues of women's agency and ambivalence. In concluding, the theoretical notion of ambivalence is employed to illustrate why women uphold and accept the hegemonic discourse of sexuality that produces gender inequity, and why the hegemonic discourse of sexuality appears to be so resilient to change. Pettinen's and Nencel's papers demonstrate the centrality of sexuality in the identity work of people in two vastly different organizational spaces, focussing respectively on dancers and secretaries. .

In concluding the issue, our final paper 'Free At Last?' by Torkild Thanem offers a critical investigation of the assembling, production and organization of female and male sexuality and sexual spaces in contemporary Swedish sex education. Focusing on booklets and leaflets published by the Swedish Association for Sexuality Education (the RFSU), Thanem re-reads Deleuze and Guattari's concept of assemblages through Irigaray's feminist philosophy to examine how the RFSU material promotes, assembles, produces and organizes sexual spaces of female and male embodiment (i.e. bodily zones, passages, surfaces, interiors, extensions, orifices and cavities). It is Thanem's argument that while the RFSU assemblages may express a celebratory attitude towards sexual diversity, freedom and enjoyment, the extent to which they undo a dichotomous and stereotypical organization of sexuality and gender is limited. In exploring this binary reduction, the paper discusses what implications this may have for 
organization theory to rethink relations between sexuality and gender, sex roles and gender roles. It further argues that examining assemblages and space through sexuality may complexify the field's understanding of organizational assemblages and spatialities.

The papers offered in this issue have in their own ways questioned some of the taken for granted assumptions surrounding sexuality by considering sexuality in relation to space. In particular, Steyaert and Green et al. have considered the inextricable relations between sexuality, difference and spatiality. It is our view that future research on sexual spaces requires a focus on the ways in which sexuality is performed, expressed and enacted in various spatial contexts of work and organization, and the ways in which this may disrupt and enable various spaces and forms of work and organization. Moreover, more work is needed to understand the ways in which queer sexualities are restricted and performed in various spaces and forms of work and organization. Although some of this work is appearing in the mainstream (see e.g. Ward and Winstanley, 2003), and even though sexual politics have made significant progress in many parts of the world (Matthias, 2007), scholars need to critically interrogate neglected cultural dimensions, cross-cultural differences on policy and practice in the oppression of marginalized groups, and the centrality of the body in managing space. This may lead us to explore whether we need a different kind of politics and whether this is a politics of the body. If that is the case, we will also need research areas that at this present time are taboo, untouchable, unspeakable and controversial, and that often are seen as backstage activities.

In closing this issue we thank David Knights and Deborah Kerfoot for providing the space in Gender, Work and Organization for this issue. We are indebted to Annie Dempsey for her assistance on this issue. Alison also thanks David Knights for acting as editor of Torkild's 
paper. The issue would not have been possible without the reviewers to this issue for their time and expertise. Last we must not forget those people who are not free to conduct their lives as they wish.

\section{References}

Adam, B. (2004) Time. Cambridge: Polity.

Adam, B. (2006) Time. Theory, Culture \& Society, 23, 2-3, 119-126.

Adkins, L. (1995) Gendered Work. Sexuality, Family and the Labour Market. Bristol: Open University Press.

Armitage, J. (2001) Virillo Live: Selected Interviews. London: Sage.

Baugh, S.G. (1997) On the persistence of sexual harassment in the workplace. Journal of Business Ethics, 16, 9, 899-908.

Bauman, Z. (1998) Globalization: The Human Consequences. Columbia: Columbia University Press.

Bell, D. (2006) Bodies, technologies, spaces: On “dogging”. Sexualities, 9, 4, 387-407.

Bell, D. and Jayne, M. (eds) (2004) City of Quarters: Urban Villages in the Contemporary City. Ashgate: Aldershot

Berg, P.O. and Kreiner, K. (1990) Corporate architecture: Turning physical settings into symbolic resources. In Gagliardi, P. (ed.) Symbols and Artifacts: Views of the Corporate 
Landscape, pp. 41-67. Berlin: de Gruyter.

Binnie, J. and Valentine, G. (1995) Mapping Desire: Geographies of Sexualities. London: Routledge.

Binnie, J. and Skeggs, B. (2004) Cosmopolitan knowledge and the production and consumption of sexualized space: Manchester's gay village. Sociological Review, 52, 1, 3961.

Brewis, J. (2005) Signing my life away? Researching sex and organization. Organization, 12, 4, 493-510.

Brewis, J. and Linstead, S. (2000) Sex, Work and Sex Work: Eroticizing Organization. London: Routledge.

Burrell, G. (1984) Sex and organizational analysis. Organization Studies, 5, 1, 97-118.

Burrell, G. (1987) No accounting for sexuality. Accounting, Organizations and Society, 12, 1, 89-101.

Burrell, G. and Dale, K. (2003) Building better worlds? Architecture and Critical Management Studies. In Alvesson, M. and Willmott, H. (eds), Studying Management Critically, pp. 177-196. London: Sage.

Capper, C.A. (1999) (Homo)sexualities, organizations, and administration: Possibilities for in(queer)y. Educational Researcher, 28, 5, 4-11. 
Carr, A. and Hancock, P. (2006) Space and time in organizational change management. Journal of Organizational Change Management, 19, 5, 545-557.

Castells, M. (2000) The Rise of the Network Society. Oxford: Blackwell.

Collinson, M. and Collinson, D. (1996) "It's only dick": The sexual harassment of women managers in insurance sales. Work, Employment \& Society, 10, 1, 29-56.

Dale, K. (2005) Building a social materiality: Spatial and embodied politics in organizational control. Organization, 12, 5, 649-678.

Elias, N. (1992) Time: An Essay. Oxford: Blackwell.

Filby, M.P. (1992) "The figures, the personality and the bums": Service work and sexuality. Work, Employment \& Society, 6, 1, 23-42.

Fleming, P. and Spicer, A. (2004) "You can checkout anytime, but you can never leave": Spatial boundaries in a high commitment organization. Human Relations, 57, 1, 75-94.

Giddens, A. (1984) The Constitution of Society. Cambridge: Polity.

Giddens, A. (1990) Consequences of Modernity. Cambridge: Polity.

Grosz, E. and Probyn, E. (1995) Space, Time, and Perversion: Essays on the Politics of Bodies. New York: Routledge.

Hatch, M.J. (1987) Physical barriers, task characteristics, and interaction activity in research and development firms. Administrative Science Quarterly, 32, 3, 387-399. 
Hearn, J. and Parkin, W. (1995) Sex at Work: The Power and Paradox of Organization Sexuality. New York: St. Martin's Press.

Hearn, J. and Parkin, W. (2001) Gender, Sexuality and Violence in Organizations: The Unspoken Forces of Organization Violations. London: Sage.

Hearn, J., Sheppard, D.L., Tancred-Sheriff, P. and Burrell, G. (eds) (1989) The Sexuality of Organization. London: Sage.

Hubbard, P.J. (1999) Sex and the City: Geographies of Prostitution in the Urban West. London: Ashgate.

Hubbard, P.J. (2001) Sex zones: Intimacy, citizenship and public space. Sexualities, 4, 1, 5171.

Hubbard, P. and Saunders, T. (2003) Making space for sex work: Female street prostitution and the production of urban space. International Journal of Urban and Regional Research, $27,1,75-89$.

Kerfoot, D. and Knights, D. (1998) Managing masculinity in contemporary organizational life: A managerial project. Organization, 5, 1, 7-26.

Linstead, S. and Pullen, A. (2006) Gender as multiplicity: Desire, displacement, difference and dispersion. Human Relations, 59, 9, 1287-1310.

Matthias, S. (2007) Pink planet. New Statesman. $23^{\text {rd }}$ July, pp.32-36. 
Schippers, M. (2000) The social organization of sexuality and gender in alternative hard rock: An analysis of intersectionality. Gender \& Society, 14, 6, 747-764.

Skeggs, B., Moran, L., and Tyrer, P. (2005) Queer as folk: Producing the real of urban space. Urban Studies, 41, 9, 1839-1856.

Soja, E.W. (1994) Thirdspace: Journeys to Los Angeles and Other Real and Imagined Places. Blackwell: Oxford.

Valentine, G. (1993) Negotiating and managing multiple sexual identities: Lesbian time-space strategies. Transactions of the Institute of British Geographers, New Series, 18, 2, 237-248.

Ward, J. and Winstanley, D. (2003) The absent presence: Negative space within discourse and the construction of minority sexual identity in the workplace. Human Relations, 56, 10, 1255 1280. 